\title{
Flux and transport of larval weakfish in Delaware Bay, USA
}

\author{
P. M. Rowe*, C. E. Epifanio \\ College of Marine Studies, Hugh R. Sharp Campus, University of Delaware, Lewes, Delaware 19958, USA
}

\begin{abstract}
We used measurements of larval abundance and longitudinal, tidal velocity to calculate flux of weakfish Cynoscion regalis larvae on the spawning grounds in southern Delaware Bay, USA. Mean flux was significantly greater during flood phase for both early-stage and late-stage larvae, but there was no difference between flood and ebb flux for yolksac larvae. We developed a new concept, larval velocity, which quantifies the subtidal velocity with which larvae are transported in an estuary. We also constructed a mathematical model that allows comparison of mean larval velocity and mean subtidal current velocity in an estuary. Larval velocity and water velocity were similar at all depths in Delaware Bay for yolksac larvae. Larval velocity was always landward (up-estuary) for more advanced larval stages and was considerably greater than subtidal water velocity, especially near the surface. Results are explained in terms of selective tidal stream transport.
\end{abstract}

KEY WORDS: Transport · Flux · Fish larvae - Weakfish · Mathematical model - Estuary · Delaware Bay

\section{INTRODUCTION}

There have been many recent studies of larval transport in estuaries, but few have attempted to quantify larval flux (for reviews see Boehlert \& Mundy 1987, Epifanio 1988). Direct estimates of larval flux require repetitive measurements of both larval abundance and tidal velocity through some known cross-sectional area of an estuary. This type of study has been conducted for crustacean larvae in small estuaries on both the Atlantic and Pacific coasts of the USA (Christy \& Stancyk 1982, Johnson \& Gonor 1982) and in a mangrove system on the Pacific coast of Costa Rica (Dittel et al. 1991). In a different approach to the problem, Kimmerer \& McKinnon (1987) calculated flux of copepods in an Australian estuary with a model that considered vertical migration of the copepods and rates of horizontal mixing in the estuary. In another study, Fortier \& Leggett (1983) determined that herring larvae in the St. Lawrence Estuary undertook tidally rhythmic, vertical migration in the water column, but

\footnotetext{
-Present address: GIROQ, Universite Laval, Ste. Foy, Quebec Canada G1K 7P4
}

subsequent modelling of their results did not yield landward transport of the larvae. In a later study, Fortier \& Leggett (1985) followed a surface drogue that remained within the same larval patch over several days and concluded that surface-oriented capelin larvae are transported seaward by subtidal drift.

In a strictly mathematical approach, Hill (1991a, b, c) has shown that larvae undergoing vertical migration at tidal frequencies in a tidal system could be transported unidirectionally, while larvae migrating at different frequencies would be retained within a bounded area. In another model that included both the semidiurnal $\left(\mathrm{M}_{2}\right)$ component and several lower-frequency, tidal components, Burger (1992) found that weakfish larvae migrating vertically at the same frequency as the $M_{2}$ tides in Delaware Bay, USA, were always transported up-estuary, while the fate of those migrating at a diel frequency depended on the date of spawning. Distributional data on larval and juvenile weakfish in Delaware Bay indicate that transport occurs from the spawning grounds in the southern bay to nursery areas $100 \mathrm{~km}$ to the north (Feingold 1989, Paperno 1991). In an earlier paper, we have shown that selective tidal stream transport is a likely mechanism for the estuarine retention of weakfish larvae (Rowe \& Epifanio 1994 
this issue). Selective tidal stream transport allows upstream transport in estuaries because larvae migrate upward in the water column on flooding tides and downward in the water column on ebbing tides. In the present paper, we quantify this process using a flux model.

\section{METHODS AND MATERIALS}

We made hourly collections of weakfish Cynoscion regalis larvae at a station on the spawning grounds in southern Delaware Bay during 1988 and 1989 (Rowe \& Epifanio 1994). Each hour's sampling consisted of 1 plankton net ( $1 \mathrm{~m}$ diameter, $383 \mu \mathrm{m}$ mesh) tow at each of 3 depths ranging from surface to near-bottom $(1,5$, and $9 \mathrm{~m}$ ). In the laboratory we sorted weakfish larvae into 3 size classes: (1) yolksac; (2) early-stage $(<3 \mathrm{~mm}$ in notochord length, $\mathrm{NL}$ ); and (3) late-stage ( $\geq 3 \mathrm{~mm}$ NL). Larvae collected in 1989 were not analyzed separately by size class because of low numbers of larvae that consisted of approximately $93 \%$ post-yolksac stage. Current velocity was also measured every $15 \mathrm{~min}$ at 2 depths ( 2 and $7 \mathrm{~m}$ above the bottom) using moored current meters. In 1988, we collected 92 h of biological samples (with 2 gaps of 10 and $12 \mathrm{~h}$ ) along with $114 \mathrm{~h}$ of current-meter data. In 1989, we measured 141 h of both larval abundance and tidal velocity without gaps.

We calculated depth-averaged larval abundance (larvae $\mathrm{m}^{-3}$ ) for each hour of sampling, and we computed depth-averaged longitudinal velocities $\left(\mathrm{m} \mathrm{s}^{-1}\right)$ as the average from the upper and lower current meter for each hour. We represented flood-phase (landward) velocities as positive values and ebb (seaward) velocities as negative values. For each hour of sampling, we determined the instantaneous larval flux (larvae $\mathrm{m}^{-2}$ $\mathrm{s}^{-1}$ ) as the product of depth-averaged larval abundance and depth-averaged longitudinal velocity. We compared absolute values of flood and ebb fluxes by nonparametric Mann-Whitney $U$-tests $(\alpha=0.05)$. We used mean flux values for every 2 consecutive hours of sampling in this analysis. This was done because earlier work had shown that consecutive hourly values of larval abundance were correlated (Rowe \& Epifanio 1994).

In addition to flux, we estimated the transport of larvae at the station. In this analysis we defined larval transport as the integration of larval flux between 2 selected times (Dittel et al. 1991). We calculated larval transports (larvae $\mathrm{m}^{-2}$ ) for time intervals between beginning and end of each flood and ebb tidal stage by summing the hourly values for flux (larvae $\mathrm{m}^{-2} \mathrm{~h}^{-1}$ ). The absolute values of successive flood and ebb transports were analyzed by Friedman's Random Block test $(\alpha=0.05)$.
We then developed a model utilizing our data for larval abundance and longitudinal velocity. This model calculates flux at each depth in the water column from surface to bottom. Physical data for the model were the time series of longitudinal velocities from both the upper and lower current meters, while biological data were hourly larval abundances at surface, mid-depth, and bottom. For each hour $(t)$ of sampling, both velocity and abundance were represented as linear functions of depth $(z)$. The function for velocity was determined by linear extrapolation from the 2 current meters, while that for abundance was determined by linear regression analysis. Because larval abundance cannot be negative, regressions with negative surface abundance were reanalyzed by regression through the origin (Zar 1984).

Instantaneous water velocity at depth $\left(U_{z t}\right)$ is expressed in $\mathrm{m} \mathrm{s}^{-1}$ and instantaneous larval abundance at depth $\left(D_{z t}\right)$ in larvae $\mathrm{m}^{-3}$. The model calculates both $U_{z t}$ and $D_{z t}$ for each depth in the water column at intervals of $1 \mathrm{~m}$ from $z=0 \mathrm{~m}$ at the surface to $z=10 \mathrm{~m}$ at the bottom. Instantaneous flux $\left(F_{z t}\right)$ at any depth $z$ (larvae $\mathrm{m}^{-2} \mathrm{~s}^{-1}$ ) is defined as the product:

$$
F_{z t}=U_{z t} \times D_{z t}
$$

After calculating instantaneous values of each variable for each hour of our study, we then averaged each of these quantities over the total number of hourly measurements in the investigation (n) for each depth $z$. These values are:

time-averaged water velocity

$$
U_{z}=\left(\sum U_{z t}\right) / n
$$

time-averaged larval abundance

$$
D_{z}=\left(\sum D_{z t}\right) / \mathrm{n}
$$

and time-averaged larval flux

$$
F_{z}=\left(\sum F_{z t}\right) / \mathrm{n}
$$

Eq. (4) represents the mean of the products of $U_{z t}$ and $D_{z t}$, and at this point, it is important to note that the mean of the products does not equal the product of the means:

$$
F_{z} \neq U_{z} \times D_{z}
$$

In the next step of the model, we divided time-averaged larval flux by time-averaged larval abundance, thus defining a unique term $\left(U_{z} \cdot\right)$, which we called 'larval velocity':

$$
U_{z}^{*}=F_{z} / D_{z}
$$

where $U_{z}^{*}$ has units of $\mathrm{m} \mathrm{s}^{-1} \cdot U_{z}^{*}$ quantifies the mean subtidal velocity at which larvae are transported in an estuary. $U_{z}{ }^{*}$ will be identical to the time-averaged or subtidal velocity of the water if larvae are well mixed 
in the water column. But if larvae undergo vertical migration, $U_{z} \cdot$ may differ from time-averaged, water velocity. In our analysis, positive values for $U_{z}^{*}$ mean that larvae are transported landward; negative values denote seaward transport.

The comparison between larval velocity and timeaveraged water velocity can reveal the mechanism of larval transport. The key to this comparison is that larval velocity $\left(U_{z}{ }^{*}\right)$ is affected by the instantaneous larval abundance at any depth $\left(D_{z t}\right)$. Because the mean of the products does not equal the product of the means, larval velocity $\left(U_{z}{ }^{\circ}\right)$ generally does not equal timeaveraged water velocity $\left(U_{z}\right)$, i.e.

$$
U_{z}^{*}=F_{z} / D_{z} \neq\left(U_{z} \times D_{z}\right) / D_{z}=U_{z}
$$

An exception to the generality of Eq. (7) occurs when larval abundance $\left(D_{2 t}\right)$ does not vary with time over the duration of the study $\left(D_{z t}=D_{z}\right)$. Under that condition larval velocity $\left(U_{z}{ }^{*}\right)$ does equal time-averaged water velocity $\left(U_{z}\right)$. Thus, for any particular depth, larval transport will approximate that of passive water particles whenever larval abundance varies little with time. In contrast, larval transport will differ from passive movement of water whenever larval abundance $\left(D_{z t}\right)$ varies significantly through time, and especially when time-averaged flux $\left(F_{z}\right)$ is large compared to the product $\left(U_{z} \times D_{z}\right)$.

\section{RESULTS}

While the time series of instantaneous, larval flux was clearly spiky, it varied at roughly the semidiumal, tidal period (Figs. $1 \& 2$ ). This spikiness was probably a consequence of the nonlinear nature of flux when calculated as a product of 2 variables. Flux maxima were 2 orders of magnitude greater in 1988 than 1989. This difference was due to the corresponding between-year ratio of larval abundance. Instantaneous flux of both earlystage and late-stage larvae was significantly greater during flood tides than during ebb tides (Table 1). However, there was no significant effect of tidal phase on flux of yolksac larvae. Longitudinal, flood transport of both early-stage and late-stage larvae was also greater than longitudinal ebb transport, and again there was no significant effect of tidal phase on yolksac larvae (Table 2).

Results of the model were analyzed by comparing larval velocity $\left(U_{z}{ }^{*}\right)$ with timeaveraged water velocity $\left(U_{z}\right), U_{z}$ was positive (landward) at all depths in 1988 (Fig. 3), but in 1989 this quantity exhibited vertical shear with seaward flow at the surface and land-
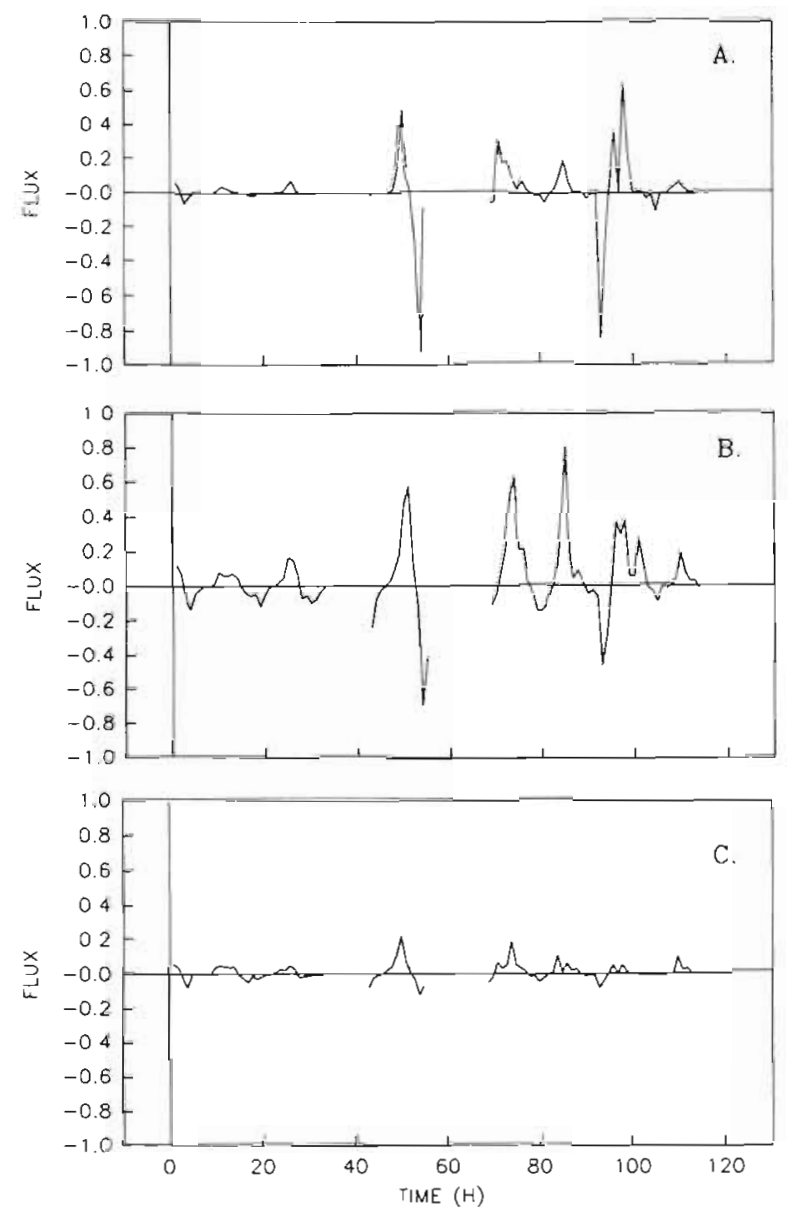

Fig. 1. Cynoscion regalis. Longitudinal flux of weakfish larvae. Positive values (larvae $\mathrm{m}^{-2} \mathrm{~s}^{-1}$ ) are landward. Series length is $114 \mathrm{~h}$ with 2 gaps of $10 \mathrm{~h}$ and $12 \mathrm{~h}$ beginning at Hour 34 and 56. The series runs from June 18 to 23, 1988. (A) Yolksac larvae. (B) Early-stage larvae. (C) Late-stage larvae

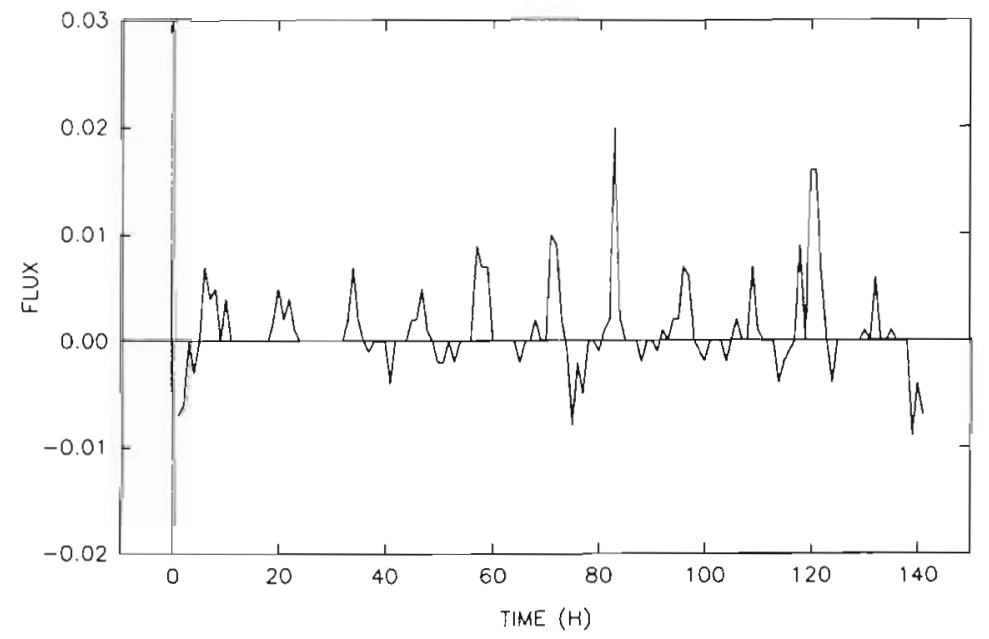

Fig. 2. Cynoscion regalis. Longitudinal flux of combined larval stages Positive values (larvae $\mathrm{m}^{-2} \mathrm{~s}^{-1}$ ) are landward. Series length is $141 \mathrm{~h}$ The series runs from May 30 to June 5, 1989 
Table 1. Cynoscion regalis. Flux of weakfish larvae along the longitudinal axis of Delaware Bay for 1988 and 1989. Larvae in 1988 are divided into 3 size classes. Larval flux is the product of depth-averaged larval abundance and depth-averaged longitudinal velocity. Absolute values for larval flux are given as larvae $\mathrm{m}^{-2} \mathrm{~s}^{-1} \times 1000$. Values in parentheses are standard errors $\times 1000$. Sample size for flood and ebb fluxes are $n=24$ and $n=21$ respectively in 1988. In 1989, $n=36$ and $n=34$ for flood and ebb fluxes respectively. Differences in larval flux between tidal stages were determined by Mann-Whitney $U$-test at $\alpha=0.05$ (Zar 1984)

\begin{tabular}{|c|c|c|c|c|}
\hline & & -1988 & L_ & \multirow{2}{*}{$\begin{array}{r}1989 \\
\text { Poolec } \\
\text { larvae }\end{array}$} \\
\hline & $\begin{array}{l}\text { Yolksac } \\
\text { larvae }\end{array}$ & $\begin{array}{c}\text { Early-stage } \\
\text { larvae }\end{array}$ & $\begin{array}{c}\text { Late-stage } \\
\text { larvae }\end{array}$ & \\
\hline Flood $(F)$ & $\begin{array}{c}75.5 \\
(19.9)\end{array}$ & $\begin{array}{l}160.8 \\
(31.5)\end{array}$ & $\begin{array}{l}41.5 \\
(7.7)\end{array}$ & $\begin{array}{c}2.9 \\
(0.5)\end{array}$ \\
\hline $\mathrm{Ebb}(\mathrm{E})$ & $\begin{array}{c}70.9 \\
(38.4)\end{array}$ & $\begin{array}{r}83.2 \\
(24.0)\end{array}$ & $\begin{array}{l}18.5 \\
(4.8)\end{array}$ & $\begin{array}{c}1.1 \\
(0.3)\end{array}$ \\
\hline$U$-test & $F=E$ & $F>E$ & $F>E$ & $F>E$ \\
\hline
\end{tabular}

ward flow near the bottom (Fig. 4). This difference is typical of the high-frequency variation in subtidal flow that occurs in Delaware Bay (Wong \& Garvine 1984, Garvine 1991). In contrast, $U_{z}{ }^{*}$ was always landward at all depths for all size classes. However, $U_{z}$ ' for yolksac larvae approximated time-averaged water velocity, while $U_{z}^{*}$ for the 2 larger size classes was always greater than time-averaged water velocity. For earlystage larvae, $U_{z}^{*}$ is about $5 \mathrm{~cm} \mathrm{~s}^{-1}$ greater than water velocity at all depths. For late-stage larvae, $U_{z}{ }^{*}$ is about $5 \mathrm{~cm} \mathrm{~s}^{-1}$ greater than water velocity at the bottom, but then rapidly increases to $25 \mathrm{~cm} \mathrm{~s}^{-1}$ greater than time-averaged water velocity at the surface. The pattern seen for the pooled larval stages in 1989 was similar to that for late-stage larvae in 1988.

Table 2. Cynoscion regalis. Transport of weakfish larvae along the longitudinal axis of Delaware Bay for 1988 and 1989. Larvae in 1988 are divided into 3 size classes. Absolute values of larval transport given as larvae $\mathrm{m}^{-2}$ Values in parentheses are standard errors. Sample size for flood and ebb transport are $\mathrm{n}=5$ in 1988 and $\mathrm{n}=11$ in 1989. Differences in larval transport between tidal stages were determined by

Friedmans Random Block analysis at $\alpha=0.05$ (Zar 1984)

\begin{tabular}{|c|c|c|c|c|}
\hline & $\begin{array}{l}\text { Yolksac } \\
\text { larvae }\end{array}$ & $\begin{array}{c}1988 \\
\text { Early-stage } \\
\text { larvae }\end{array}$ & $\begin{array}{c}\text { Late-stage } \\
\text { larvae }\end{array}$ & $\begin{array}{l}1989 \\
\text { Pooled } \\
\text { larvae }\end{array}$ \\
\hline Flood $(F)$ & $\begin{array}{l}1440 \\
(780)\end{array}$ & $\begin{array}{c}3053 \\
(1002)\end{array}$ & $\begin{array}{l}706 \\
(78)\end{array}$ & $\begin{array}{c}68 \\
(12)\end{array}$ \\
\hline Ebb (E) & $\begin{array}{l}1162 \\
(810)\end{array}$ & $\begin{array}{l}1451 \\
(436)\end{array}$ & $\begin{array}{l}313 \\
(75)\end{array}$ & $\begin{array}{l}21 \\
(6)\end{array}$ \\
\hline Block analysis & $S F=E$ & $F>E$ & $F>E$ & $F>E$ \\
\hline
\end{tabular}

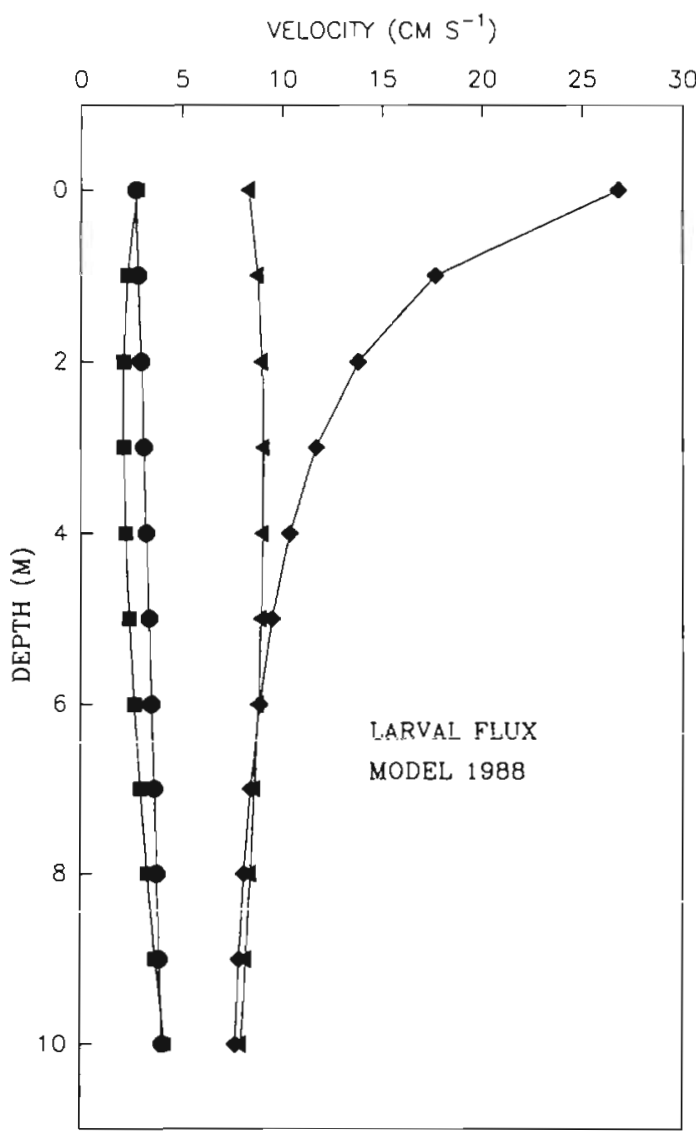

Fig. 3. Cynoscion regalis. Velocity profiles from the larval flux model for 1988. Modelled time-averaged water velocity and modelled larval velocity ( $\mathbf{\square}$ : yolksac; 4 : early-stage; late-stage) are presented with depth. Positive velocity values are landward

\section{DISCUSSION}

Results of our statistical analysis show clear ontogenetic changes in both flux and transport of weakfish larvae. Specifically, there was no effect of tidal phase on either flux or transport of yolksac larvae, while both transport and flux were significantly greater during flood phase for more advanced stages. Unlike earlier flux studies of crustacean larvae (Christy \& Stancyk 1982, Johnson \& Gonor 1982, Dittel et al. 1991), we made no attempt to extrapolate unit flux-values measured at our station to the whole cross section of the estuary. A critical assumption in those earlier investigations was that larval abundance is uniform in cross section; this assumption is clearly invalid in a large estuary like Delaware Bay where larval abundance varies greatly in the horizontal plane (Goshorn \& Epifanio 1991). Nevertheless, our station was located in the center of the major weakfish spawning grounds in Delaware Bay (Feingold 1989, Goshorn \& Epifanio 


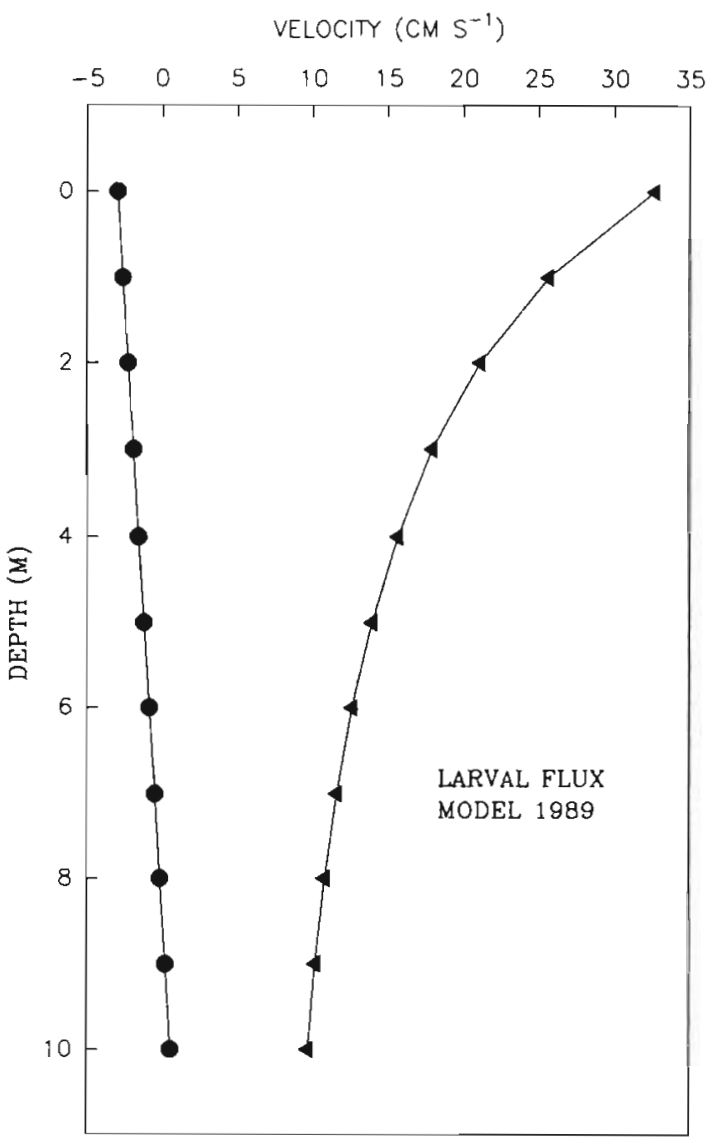

Fig. 4. Cynoscion regalis. Velocity profiles from the larval flux model for 1989. Modelled time-averaged water velocity (-) and modelled larval velocity ( 4 : combined stages) are presented with depth. Positive velocity values are landward

1991) and our estimates of flux and transport are relevant to transport of larval weakfish in the estuary as a whole.

The velocity of yolksac larvae was approximately equal to the modelled, time-averaged water velocity at all depths. Therefore yolksac larvae were passively transported as part of the general subtidal circulation of the estuary. In contrast, velocities for early-stage and late-stage larvae were always greater than modelled, time-averaged water velocity; thus early-stage and late-stage larvae were not passively transported. Because swimming speeds of fish larvae are only 1 to 2 body lengths $\mathrm{s}^{-1}$ (Miller et al. 1984) (3 to $6 \mathrm{~mm} \mathrm{~s}^{-1}$ for weakfish), horizontal swimming cannot be considered important to overall transport. Rather, an active transport mechanism, e.g. selective tidal stream transport, is indicated. Indeed, this mechanism has been inferred in an earlier analysis of these data (Rowe \& Epifanio 1994). The shape of the larval velocity profile for latestage larvae in 1988 and for pooled larvae in 1989 suggests that larvae appear in surface waters only during flood tides. That is, late-stage larvae make positive (flood) contributions to flux at the surface, but make both positive and negative contributions to flux at depth. Thus larval velocity is greater at the surface than at the bottom, and older larvae appear to be retained and transported up-estuary.

This larval flux model is a preliminary attempt to quantify the transport of weakfish larvae in Delaware Bay. The model is clearly an approximation because: (1) bottom shear was not considered in the linear extrapolation of tidal velocity in the water column; and (2) the vertical distribution of larval abundance was represented as a linear regression of only 3 points. Nevertheless, the model presents an interesting new concept, i.e. larval velocity, and allows a clear graphical comparison of larval velocity and time-averaged water velocity for each depth in the water column. While the modelled values are not intended for literal interpretation, the time-averaged values for water velocity are reasonable compared to actual subtidal velocities previously measured in the bay (Pape \& Garvine 1982, Wong \& Garvine 1984, Garvine 1991), and we have no reason to suspect that our values for larval velocity are any less reasonable.

Acknowledgements. We thank our colleague, Dr Richard Garvine, for suggesting the model and for help in conceptualizing the larval transport term. Drs James Power and Timothy Targett read an early draft of the manuscript. Nita Gary and Vikki Connaughton helped in preparing the mansucript and figures. The study was supported by funds provided by the Wallop-Breaux Sport Fish Restoration Act. Funds were administered by the Delaware Department of Natural Resources and Environmental Control.

\section{LITERATURE CITED}

Boehlert, G. W., Mundy, B. C. (1987). Recruitment dynamics of metamorphosing English sole, Parophorys vetulus, to Yaquina Bay, Oregon. Estuar. coast. Shelf Sci. 25: 261-281

Burger, M. J. (1992). The role of light, gravity and hydrostatic pressure in controlling the vertical movements of larval weakfish (Cynoscion regalis). M.Sc. thesis, University of Delaware, Newark

Christy, J. H., Stancyk, S. E. (1982). Timing of larval production and flux of invertebrate larvae in a well-mixed estuary. In: Kennedy, V. S. (ed.) Estuarine comparisons. Academic Press, New York, p. 489-503

Dittel, A. I., Epifanio, C. E., Lizano, O. (1991). Flux of crab larvae in a mangrove creek in the Gulf of Nicoya, Costa Rica. Estuar. coast. Shelf Sci. 32: 129-140

Epifanio, C. E. (1988). Transport of invertebrate larvae between estuaries and the continental shelf. Am. Fish. Soc Symp. 3: 104-114

Feingold, L. E. (1989). Influence of physical parameters on the distribution and survivorship of the early life history stages of weakfish in Delaware Bay. M.S. thesis, University of Delaware, Newark

Fortier, L., Leggett, W. C. (1983). Vertical migrations and transport of larval fish in a partially mixed estuary. Can. J. Fish. Aquat. Sci. 40: 1543-1555 
Fortier, L., Leggett, W. C. (1985). A drift study of larval fish survival. Mar. Ecol. Prog. Ser. 25: 245-257

Garvine, R. W. (1991). Subtidal frequency estuary-shelf interaction: observations near Delaware Bay. J. geophys. Res. 96: 7049-7064

Goshorn, D. M., Epifanio, C. E. (1991). Diet of larval weakfish and prey abundance in Delaware Bay. Trans. Am. Fish. Soc. 120: $684-692$

Hill, A. E. (1991a). Advection-diffusion-mortality solutions for investigating pelagic larval dispersal. Mar. Ecol. Prog. Ser. $70: 117-128$

Hill, A. E. (1991b). Vertical migration in tidal currents. Mar. Ecol. Prog. Ser. 75: 39-54

Hill, A. E. (1991c). A mechanism for horizontal zooplankton transport by vertical migration in tidal currents. Mar. Biol. 111: $485-492$

Johnson, G. E., Gonor, J. J. (1982). The tidal exchange of Callianassa californiensis (Crustacea, Decapoda) larvae between the ocean and the Salmon River Estuary, Oregon. Estuar. coast. Shelf Sci. 14: 501-516

Kimmerer, W. J., McKinnon, A. D. (1987). Zooplankton in a marine bay. 1l. Vertical migration to maintain horizontal

This article was submitted to the editor distributions. Mar. Ecol. Prog. Ser. 41: 53-60

Miller, J. M., Reed, J. P., Pietrafesa, L. J. (1984). Patterns, mechanisms and approaches to the study of migrations of estuarine-dependent fish larvae and juveniles. In: McCleave, J. D., Arnold, G. P., Dodson, J. J., Neill, W. H (eds.) Mechanisms of migration in fishes. Plenum Press, New York, p. 209-225

Pape, E. H. III, Garvine, R. W. (1982). The subtidal circulation in Delaware Bay and adjacent shelf waters. J. geophys. Res. 87: 7955-7970

Paperno, R. (1991). Spatial and temporal patterns of growth and mortality of juvenile weakfish (Cynoscion regalis) in Delaware Bay: assessment using otolith microincrement analysis. Ph.D. thesis, University of Delaware, Newark

Rowe, P. M., Epifanio, C. E. (1994). Tidal stream transport of weakfish larvae in Delaware Bay, USA. Mar. Ecol. Prog. Ser. 110: 105-114

Wong, K.-C., Garvine, R. W. (1984). Observations of windinduced, subtidal variability in the Delaware Estuary. J. geophys. Res. 89: 10589-10597

Zar, J. H. (1984). Biostatistical analysis, 2nd edn. Prentice Hall, Inc., Englewood Cliffs: N.I

Manuscript first received: May 6, 1993

Revised version accepted: March 22, 1994 